\title{
Correction to: Whole-brain death and integration: realigning the ontological concept with clinical diagnostic tests
}

\author{
Daniel P. Sulmasy ${ }^{1}$
}

Published online: 17 December 2020

(c) Springer Nature B.V. 2020

\section{Correction to: Theoretical Medicine and Bioethics (2019) 40:455-481 https://doi.org/10.1007/s11017-019-09504-w}

In my article, "Whole-brain death and integration: Realigning the ontological concept with clinical diagnostic tests" [1], I wrote that Oderberg holds that only the death of all cells can count as the death of the organism. While I was interpreting him and not quoting him, Prof. Oderberg has correctly pointed out that he does not directly advance this claim. He states, instead, that "only putrefaction-the physical decomposition of the body — can be a certain sign that death has occurred" [2]. It should be noted, however, that autolysis, the spontaneous destruction and rupture of the cell membranes of dead organisms, begins 4 minutes after human death and, while further autolytic chemical changes might be ongoing, the twin processes of apoptosis and autophagy may be complete as early as 8 hours after death [3]. Putrefaction, the digestion of dead remains by microorganisms, follows and depends upon autolysis, beginning in the gut. The first visible sign of putrefaction, a greenish skin discoloration above the right iliac fossa, usually appears 18-36 hours after death [4, 5].

\section{References}

1. Sulmasy, Daniel P. 2019. Whole-brain death and integration: Realigning the ontological concept with clinical diagnostic tests. Theoretical Medicine and Bioethics 40: 455-481.

2. Oderberg, David S. Death, unity, and the brain. Theoretical Medicine and Bioethics 40: 359-379.

The original article can be found online at https://doi.org/10.1007/s11017-019-09504-w.

Daniel P. Sulmasy

sulmasyd@georgetown.edu

1 Kennedy Institute of Ethics, Georgetown University, Healy 419, 3700 O Street NW, Washington, DC 20057, USA 
3. Martínez, Paula Núñez., Sofia T. Menéndez, María de los Ángeles Villaronga, Douglas H. Ubelaker, Juana M. García-Pedrero, and Sara C. Zapico. 2019. The big sleep: elucidating the sequence of events in the first hours of death to determine the postmortem interval. Science and Justice 59: 418-424.

4. Almulhim, Abdulaziz M., and Ritesh G. Menezes. 2020. Evaluation of postmortem changes. StatPearls [Internet]. Updated May 29, 2020. Treasure Island, FL: StatPearls. https://www.ncbi.nlm.nih. gov/books/NBK554464.

5. Shedge, Rutwik, Kewal Krishan, Varsha Warrier, and Tanuj Kanchan. 2020. Postmortem changes. StatPearls [Internet]. Updated July 27, 2020. Treasure Island, FL: StatPearls. https://www.ncbi.nlm. nih.gov/books/NBK539741.

Publisher's Note Springer Nature remains neutral with regard to jurisdictional claims in published maps and institutional affiliations. 